\title{
ПОВЫШЕНИЕ ДОЛГОВЕЧНОСТИ ПЕРЕВОДНИКОВ И БУРИЛЬНЫХ ТРУБ ЭЛЕКТРОМЕХАНИЧЕСКОЙ ОБРАБОТКОЙ
}

\author{
С.К.ФЕДОРОВ ${ }^{1}$, Л.В.ФЕДОРОВА ${ }^{1}$, Ю.С.ИВАНОВА ${ }^{1}$, М.В.ВОРОНИНА ${ }^{2}$, А.В.САДОВНИКОВ ${ }^{3}$, В.Н.НИКИТИН $^{4}$ \\ ${ }^{1}$ Московский государственный технический университет им. Н.Э. Баумана, Москва, Россия \\ ${ }^{2}$ Санкт-Петербургский горный университет, Санкт-Петербург, Россия \\ ${ }^{3}$ ООО «Материаль Технологии Сервис», Москва, Россия \\ ${ }^{4}$ ООО «Интехно», Ханты-Мансийский автономный округ - Югра, Нижневартовск, Россия
}

Определены направления проведения исследований по повышению износостойкости замков бурильных труб, резьбовых соединений и обсадной бурильной колонны: нанесение на замок бурильных труб износостойких наплавок российскими и зарубежными материалами (хардбендинг); закалка поверхностного слоя замков бурильных труб электромеханической обработкой; закалка наружной и внутренней замковой резьбы бурильных труб электромеханической обработкой. Проведены сравнительные испытания износостойкости различных наплавочных материалов (хардбендинг) российского и зарубежного производства и замка бурильных труб без наплавок. Разработаны рекомендации по повышению износостойкости резьбовых соединений способом электромеханической обработки, которые определяют пути повышения ресурса и надежности бурильных труб и переводников, формирования уникальных свойств деталей, снижения трудоемкости изготовления и восстановления деталей, повышения эффективности работы предприятий и организаций, защиты окружающей среды и создания конкурентоспособной продукции.

Материалы статьи представляют практическую ценность для специалистов различных областей, занимающихся вопросами повышения надежности технологического оборудования.

Производственный успех использования технологии нанесения износостойких наплавок на тело бурильного замка обусловлен возможностью использования относительно простого и мобильного оборудования для сварки, проведения работ в местах использования бурильного инструмента или временных (постоянных) производственных базах с небольшим транспортным плечом от месторождения, повторного нанесения наплавочных материалов при восстановлении замков бурильных труб; широким и постоянно растущим списком компаний, которые получают аккредитацию на производство данных работ.

Ключевые слова: хардбендинг; переводники; бурильные трубы; износостойкость; резьба; поверхностный слой; электромеханическая обработка; твердость

Как цитировать эту статью: Федоров С.К. Повышение долговечности переводников и бурильных труб электромеханической обработкой / С.К.Федоров, Л.В.Федорова, Ю.С.Иванова, М.В.Воронина, А.В.Садовников, B.Н.Никитин // Записки Горного институга. 2018. Т. 233. С. 539-546. DOI: 10.31897/PMI.2018.5.539

Введение. Увеличение долговечности бурильных труб (БТ) и переводников является актуальной задачей, решение которой позволит повысить эффективность работы нефтяных компаний. Наиболее характерными дефектами БТ и переводников являются износ наружного диаметра замков и повреждение резьбы. Низкая долговечность указанных участков деталей объясняется невысокой твердостью поверхностного слоя - не более 32-36 HRC. Кроме того, недостаточная износостойкость резьбы перечисленных деталей связана с особенностями конструкции, технологическими сложностями при ее изготовлении и восстановлении, схемой нагружения витков, условиями эксплуатации резьбовых соединений при бурении, а также при сборке-разборке БТ и переводников.

Одной из проблем низкой долговечности бурильных труб является абразивный износ и износ замков при трении о внутренние стенки обсадных труб [1]. Более 60 \% труб отбраковываются из-за износа наружного диаметра замка, при этом остальные параметры трубы соответствуют допустимым нормам. Основной причиной изнашивания замков бурильных труб в открытом стволе является наличие твердого слоя в агрессивных геологических образованиях. Существующие исследования доказывают, что и при проектировании технико-технологических параметров разрушения горных пород при бурении необходимо учитывать не только их физикомеханические и деформационные характеристики, но и характер технико-технологических взаимодействий породоразрушающего инструмента с горной породой [2].

При бурении нефтяных и газовых скважин нижнюю часть бурильной колонны составляют утяжеленные бурильные трубы (УБТ), толстостенные бурильные трубы (ТБТ) и стальные бурильные трубы (СБТ). УБТ и ТБТ изготавливают из цельной заготовки конструкционных легированных сталей марок 40ХГМА, 40ХН2МА. СБТ являются составными, с замками, приварен- 
Повышение долговечности переводников и бурильных труб...

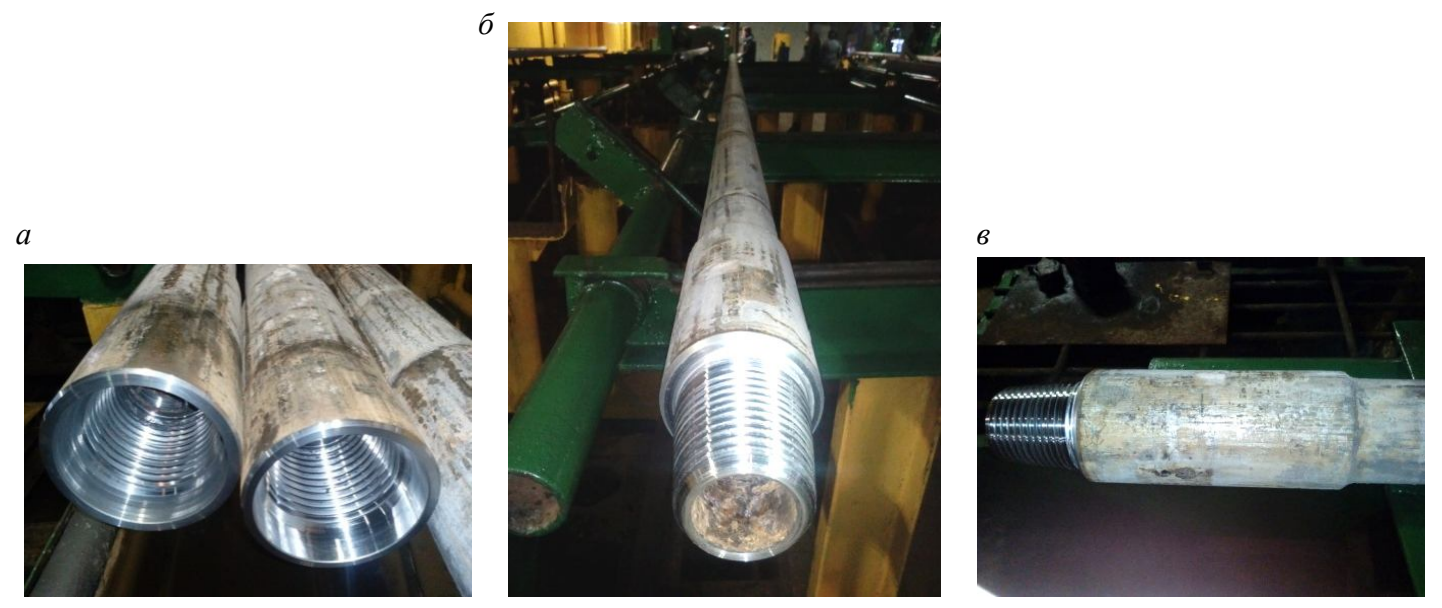

Рис.1. Стальная бурильная труба ( $a$ ), фрагменты ее муфтовой (б) и ниппельной (в) частей

ными к телу трубы сваркой трением. Каждую из перечисленных деталей СБТ (рис.1) изготавливают из качественных конструкционных низколегированных сталей и подвергают термической обработке. Длина БТ составляет 8,5-12,5 м.

Постановка проблемы. В целях повышения долговечности БТ на наружный диаметр замков наплавкой наносят пояски с износостойкими материалами. Чаще всего таких поясков три, каждый из которых имеет ширину 25,4 мм при общей ширине 76,2 6,35 мм. Наплавку поясков выполняют в среде аргона. Наплавленный металл возвышается над телом замка до 2,5 мм. Такой способ повышения долговечности БТ широко используется зарубежными компаниями [3, 11]. Таким образом, одним из приоритетных направлений при производстве и капитальном ремонте бурильных труб стала упрочняющая наплавка износостойкими материалами (хардбендинг) наружной поверхности замков. Хардбендинг - износостойкое защитное металлическое покрытие, нанесенное методом электросварки на наружную поверхность замка бурильной трубы с целью увеличения ресурса замка и уменьшения износа обсадной колонны $[6,10]$.

Не менее важной проблемой является повышение износостойкости замковой резьбы БТ. Решение указанной проблемы невозможно без увеличения поверхностной твердости витков резьбы при сохранении высоких физико-механических свойств середины витков [8]. Необходимые физико-механические свойства резьбы БТ можно обеспечить применением комбинированных методов обработки, основанных на использовании концентрированных потоков энергии.

Одним из таких методов является электромеханическая обработка (ЭМО), основанная на одновременном термомеханическом воздействии высококонцентрированного потока электрической энергии на поверхностный слой заготовок из стали и формирующая высокую твердость и мелкодисперсную структуру. Результаты исследований и опытно-экспериментальных работ указывают на возможность повышения долговечности БТ и переводников за счет целенаправленного повышения твердости наиболее нагруженных участков деталей до оптимального значения [4, 5, 7, 9, 12-14].

Методика исследования. Дальнейшее применение износостойких наплавок в составе бурильной колонны невозможно без определения степени их эффективности. С этой целью необходимо провести сравнительный анализ износостойкости различных наплавочных материалов и замков БТ без наплавок.

Приведены результаты сравнительных испытаний износостойких наплавок российских и зарубежных компаний, а также технология электромеханической обработки в сравнении с исходным состоянием бурильных замков СБТ89 в группе прочности G105 по двум тестам в соответствии со стандартом ASTM G65и CasingWearTest.

Аккредитованные сервисные компании, оказывающие услуги по нанесению износостойких наплавок, предоставили для испытаний образцы следующих параметров:

Ниппель (или муфта) замка бурильной трубы СБТ89 в группе прочности G105 Высота покрытия, мм

Ширина покрытия, мм

Вариант нанесения наплавки
Внешний диаметр замка 127 мм

$2,38(+0,8)$

$76,2 \pm 6,35$

Стандартный 
А.В.Садовников, В.Н.Никитин

Повышение долговечности переводников и бурильных труб...

На испытания были предоставлены следующие образцы (рис.2):

- исходный (ниппельная часть бурильной трубы без наплавки);

- Duraband NC (Postle Industries);

- OTW-12Ti (Castolin Eutectic);

- ARNCO 350XT (Arnco Technology Trust);

- НП 57 (Интерпро, Россия);

- НП 58 (Интерпро, Россия);

- ASM NGN-GS (ACM - специальные наплавочные материалы, Россия);

- OTW-13 CF (Castolin Eutectic);

- электромеханическая обработка (ЭМО).

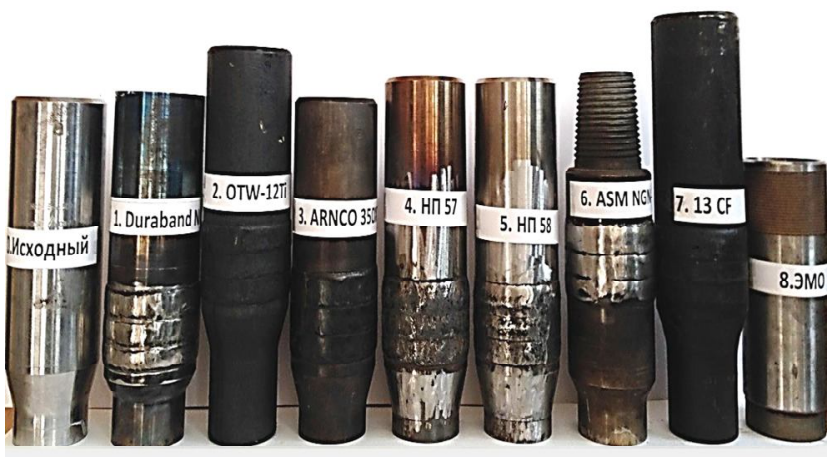

Рис. 2. Образцы для исследований

Для изготовления образцов замки СБТ 89 прошли механическую обработку: точение по наружному диаметру до устранения неровностей наплавки; растачивание внутреннего диаметра до 105 мм; отрезание кольца высотой $20 \pm 0,1$ мм. Кольцо разрезали на сегменты длиной 35 мм. Из каждого кольца отрезали четыре сегмента, три из которых использовали для износных испытаний, а один образец - для металлографических исследований.

Параметры представленных образцов:

\footnotetext{
Муфта замка бурильной трубы

Наружный диаметр замка, мм

Высота наплавки, мм

Ширина наплавки, мм

Вариант нанесения наплавки
}

СБТ 89 в группе прочности G105

$$
\begin{gathered}
127 \\
2,38(+0,8) \\
76,2 \pm 6,35 \\
\text { Стандартный }
\end{gathered}
$$

Принципиальная схема износных испытаний приведена на рис.3. Образец неподвижно закреплен на основании маятникового рычага, с торца которого ввинчивается рычаг. На правый край рычага подвешивается груз, который обеспечивает постоянную нагрузку в зоне контакта

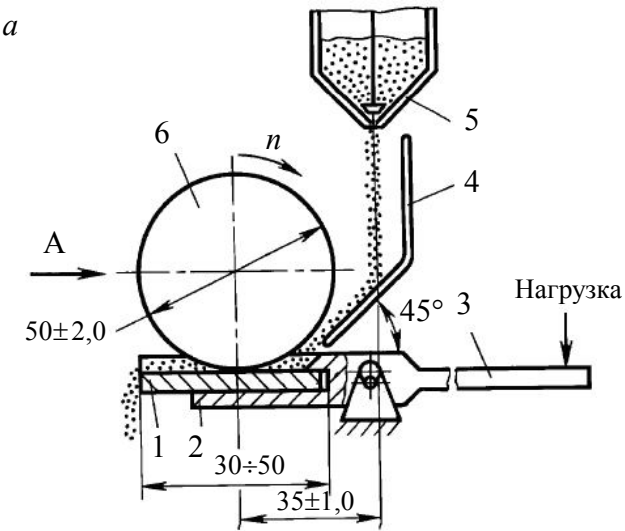

6
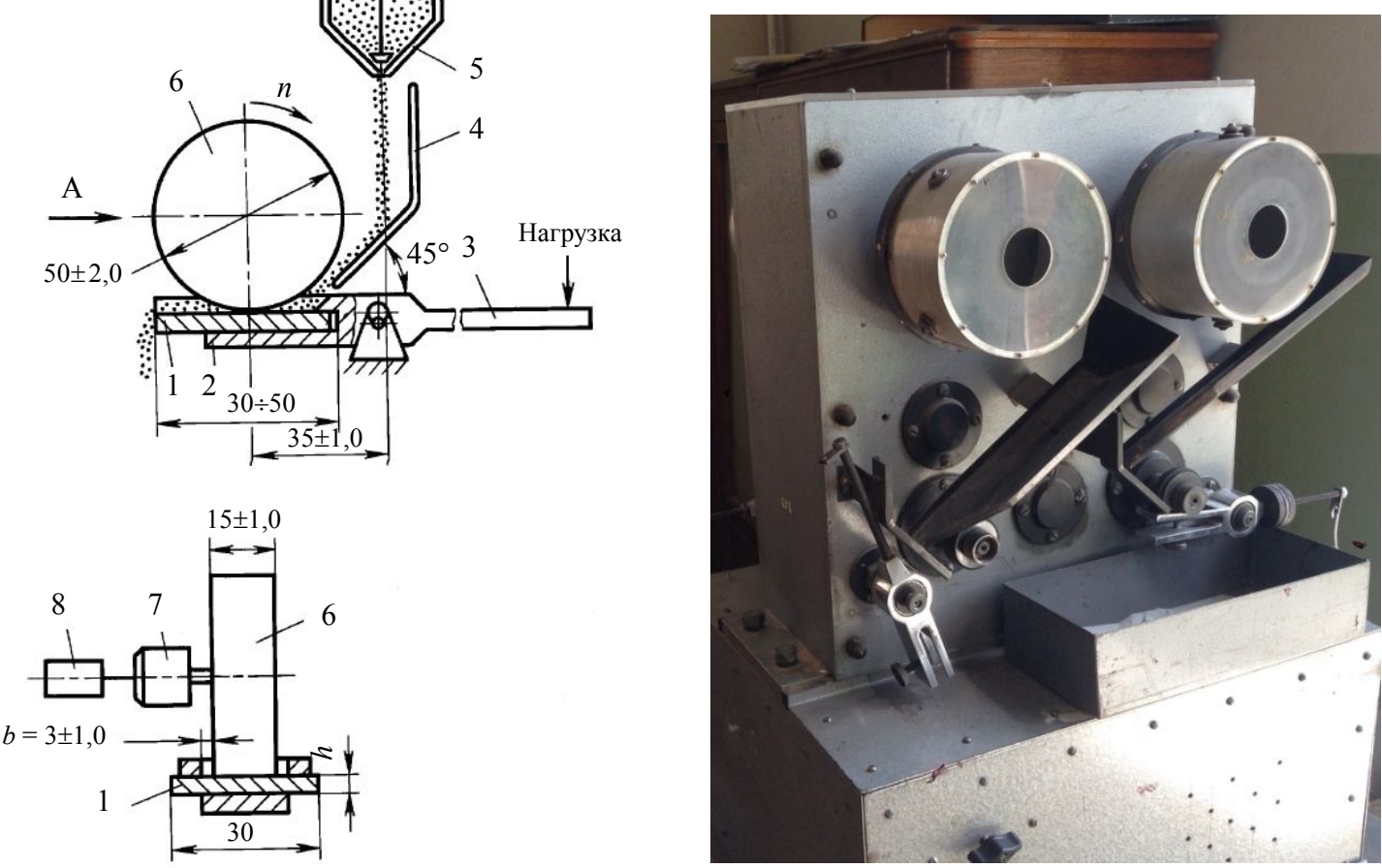

Рис.3. Принципиальная схема испытаний ( $a$ ) и фотография стенда (б)

1 - образец; 2 - рычаг маятниковый; 3 - рычаг; 4 - направляющий лоток;

5 - дозатор подачи абразивных частиц; 6 - резиновый ролик; 7 - привод; 8 - счетчик контроля суммарного количества оборотов ролика 
Повышение долговечности переводников и бурильных труб...

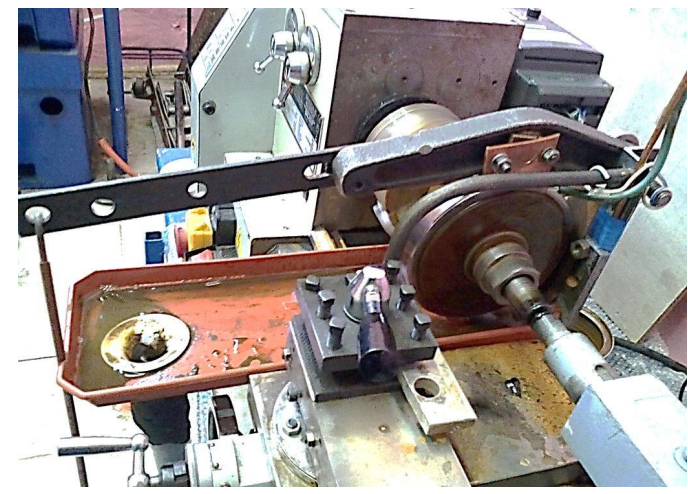

Рис.4. Стенд для проведения испытаний (тест Casing Wear Test)

образца и вращающегося резинового ролика. Через вращающийся дозатор по направляющему лотку в зону контакта образца и резинового ролика подается абразив зернистостью 16 мкм. Продолжительность испытаний, установленная стандартами ASTM G65 и ГОСТ 23.208-79, составляла 30 мин на каждый образец.

Стенд (рис.4.) для проведения износных испытаний замка БТ и обсадных труб (тест Casing Wear Test) оснащен:

- системой частотного регулирования для соблюдения точных и необходимых параметров частоты вращения (155 об/мин);

- рычажным механизмом, обеспечивающим необходимые параметры прижатия образца наплавки к обсадной трубе;

- устройством подачи в зону контакта «обсадная труба - наплавка» жидкого бурового рас-

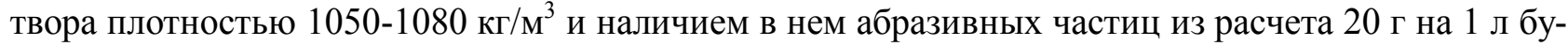
рового раствора.

Химический анализ образцов проводили на лазерном атомно-эмиссионном спектрометре «ЛАЭС». Шлифы готовили по стандартной методике на оборудовании для пробоподготовки «Stuers». Травление образцов осуществляли в $4 \%$-ном растворе азотной кислоты в этиловом спирте. Травление наплавленного металла на образцах проводили в реактиве Марбле (20 г $\mathrm{CuSO}_{4}, 100$ мл $\mathrm{HCl}, 100$ мл этилового спирта).

Металлографические исследования проводили на оптическом микроскопе Carl Zeiss AxioObserver.D1m при увеличениях от 200 до 1000 крат. Микротвердость измеряли на твердомеpe DuraScan 70 при нагрузке 100 г.

Результаты исследования и их интерпретация. В процессе бурения скважин нижняя часть бурильной колонны находится в непосредственном контакте с абразивными частицами породоразрушающих пластов. Интенсивность разрушения поверхностных слоев БТ при абразивном износе практически не зависит от исходных прочностных свойств материала замков. Химический состав материала замков $[5,6]$ бурильных труб указывает на значительный разброс сталей по содержанию углерода $(0,22-0,37)$, что в сочетании с другими легирующими элементами соответствует маркам сталей 20ХГНМ-38ХГНМ. Твердость материала замковой части БТ составляет 28-36 НRC и обеспечивается индукционной объемной термической обработкой.

Легирующие элементы хром, марганец, молибден, никель значительно повышают прокаливаемость стали. Эффект прокаливаемости усиливается при легировании стали несколькими элементами.

Все легирующие элементы уменьшают критическую скорость закалки.

Следовательно, в легированных сталях твердость можно увеличить при охлаждении с меньшими скоростями, чем в углеродистых сталях. Кроме того, закалку легированных сталей можно проводить в менее резких охладителях, что снизит вероятность возникновения дефектов закалки, в первую очередь закалочных трещин. Это особенно важно для БТ и замка, соединяемых между собой контактной сваркой трением.

Результаты износных испытаний образцов по ASTM G65 следующие:

$\begin{array}{lccccccccc}\text { Номер } & 0 & 1 & 2 & 3 & 4 & 5 & 6 & 7 & 8 \\ \text { Образец } & \text { Исходный } & \text { Duraband NC } & \text { OTW-12Ti } & \text { ARNCO 350 XT } & \text { HП 57 } & \text { HП 58 } & \text { ASM NGN-GS } & 13 \text { CF } & \text { ЭMO } \\ \text { Износ, г } & 0,2869 & 0,0534 & 0,1185 & 0,0944 & 0,0615 & 0,0644 & 0,1220 & 0,0628 & 0,1213\end{array}$

Испытания наплавленных материалов в сравнении с материалами замков серийного производства свидетельствуют об эффективности всех исследуемых образцов. В целом сохраняется зависимость износостойкости от твердости материала наплавок.

Испытания (тест Casing Wear Test) показали высокую износостойкость замков БТ всех наплавочных материалов (табл.1). Подтверждена закономерность о том, что материалы с относительно невысокой твердостью наплавок в меньшей степени изнашивают образец обсадной трубы 
А.В.Садовников, В.Н.Никитин

Повышение долговечности переводников и бурильных труб...

(табл.2), а износостойкость наплавленной поверхности замка более чем в 5 раз превышает износостойкость исходных образцов.

Следует отметить, что замки БТ, закаленные ЭМО (рис.5), показали повышение износостойкости более чем в 3 раза в сравнении с исходными трубами без наплавки. Износостойкость обсадных труб в контакте с образцами замков БТ после ЭМО повысилась в 2,8 раза (табл.2).

Таблица 1

Результаты износа контробразцов (наплавок)

\begin{tabular}{l|c|c|c|c|c|c}
\hline \multirow{2}{*}{ Образец } & \multicolumn{5}{|c|}{ Масса образца бурильной трубы, г } & \multirow{2}{*}{ Износ образца } \\
\cline { 2 - 6 } & Исходная г & 2 ч & 4 ч & 6 ч & 8 ч & 2,10 \\
\hline Исходный & 592,80 & 591,20 & 591,00 & 590,80 & 590,70 & 0,60 \\
Duraband NC & 765,50 & 765,20 & 765,00 & 765,95 & 764,90 & 0,20 \\
OTW-12Ti & 692,30 & 692,25 & 692,20 & 692,15 & 692,10 & 0,35 \\
ARNCO 350XT & 722,25 & 722,10 & 722,00 & 721,95 & 721,90 & 0,75 \\
HП 57 & 721,80 & 721,60 & 721,40 & 721,20 & 721,05 & 0,25 \\
HП 58 & 720,80 & 720,70 & 720,65 & 720,60 & 720,55 & 0,30 \\
ASM NGN-GS & 718,10 & 718,00 & 717,95 & 717,90 & 717,80 & 0,45 \\
13 CF & 614,80 & 614,50 & 614,45 & 614,40 & 614,35 & 0,60
\end{tabular}

Таблица 2

Результаты износа образцов обсадной трубы

\begin{tabular}{|c|c|c|c|c|c|c|}
\hline \multirow{2}{*}{ Образец } & \multicolumn{5}{|c|}{ Масса образца бурильной трубы, г } & \multirow{2}{*}{$\begin{array}{c}\text { Износ образца } \\
\text { замка, г }\end{array}$} \\
\hline & Исходная & 2 ч & 4 ч & 6 ч & 8 ч & \\
\hline Исходный & 65,2 & 60,9 & 59,5 & 58,6 & 57,2 & 8 \\
\hline Duraband NC & 65,9 & 64,9 & 64,3 & 63,9 & 63,4 & 2,5 \\
\hline OTW-12Ti & 64,6 & 64,2 & 63,8 & 63,3 & 63 & 1,6 \\
\hline ARNCO 350XT & 63,5 & 62,3 & 61,7 & 61,3 & 60,8 & 2,7 \\
\hline НП 57 & 65,1 & 64,3 & 63,8 & 63,1 & 62,6 & 2,5 \\
\hline НП 58 & 64,9 & 64,3 & 63,8 & 63,1 & 62,6 & 2,3 \\
\hline ASM NGN-GS & 64,1 & 63,2 & 62,5 & 62 & 61,7 & 2,4 \\
\hline $13 \mathrm{CF}$ & 65,2 & 64,2 & 63,5 & 62,9 & 62,6 & 2,6 \\
\hline ЭМО & 63,3 & 62,2 & 61,7 & 61 & 60,2 & 3,1 \\
\hline
\end{tabular}

Для определения эффективности износостойких наплавок на изменение наружного диаметра замков СБТ 86 в условиях трубной базы ООО «БИС-Сервис» (г.Нижневартовск) использовали метрологические измерения. СБТ 86 поступили на ремонт в связи с выбраковкой их по наружной и внутренней замковой резьбе. Измерения наружного диаметра замков проводили штангенциркулем ШЦ 250 с точностью 0,05 мм. Выявлено, что в составе одной бурильной колонны использовали как СБТ 86 с наплавленными по наружному диаметру поясками (наплавка BoTn 3000), так и трубы с замками без наплавки (рис.6).

Наружный диаметр замков СБТ 86 без наплавки составил 103,5-104,8 мм, тогда как с наплавленными поясками -
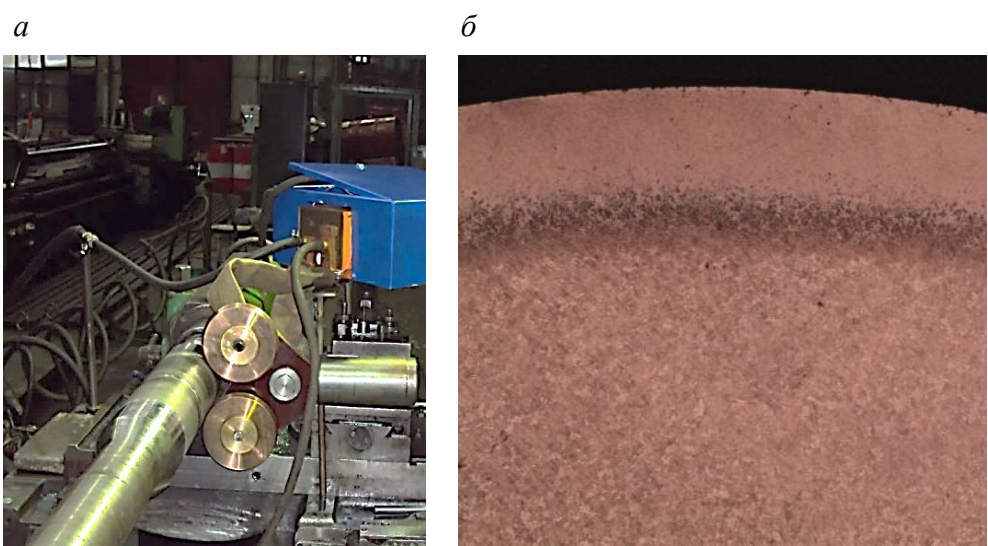

Рис.5. Фрагмент ЭМО наружного диаметра замка бурильной трубы (a) и микроструктура закаленного поверхностного слоя (б) 
Повышение долговечности переводников и бурильных труб..

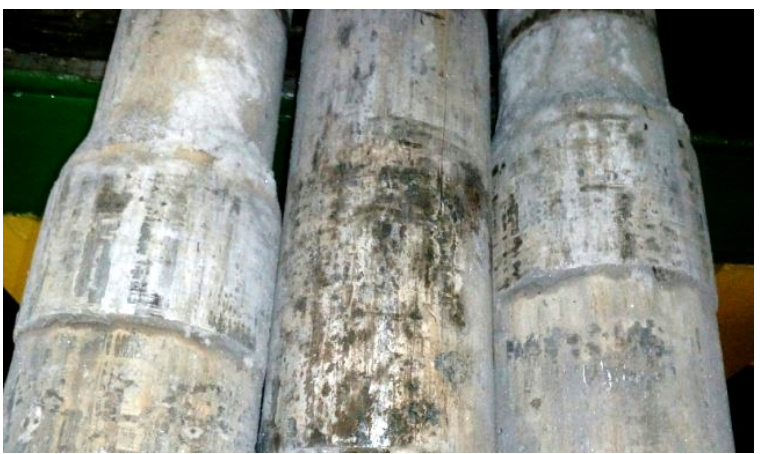

Рис.6. Фрагменты замков СБТ без наплавки (в середине) и с хардбендингом

$108 \pm 0,1$ мм. Измерение наружного диаметра наплавленных участков СБТ 86 свидетельствует о незначительном износе наплавки (диаметр 110,8-112,0 мм) и отсутствии износа замков БТ. Выкрашивания и отслоения наплавленного металла не отмечено.

По результатам метрологических исследований СБТ 86, поступивших в ремонт, можно сделать следующее заключение:

- наплавка повышает долговечность деталей, способствуя повышению износостойкости замков БТ в условиях абразивного воздействия агрессивных геологических образований;

- использование БТ без износостойких наплавок недопустимо, так как дальнейшая их эксплуатация в составе бурильной колонны может привести к аварийным последствиям;

- применение в бурильной колонне труб с наплавкой и без наплавки поясков с различной степенью износа замков также недопустимо;

- в бурильной колонне необходимо применять трубы с одинаковой наплавкой замков.

Не менее важной является проблема низкой износостойкости замковой резьбы БТ и переводников. Значительный разброс сталей (20ХГНМ-38ХГНМ), используемых для изготовления
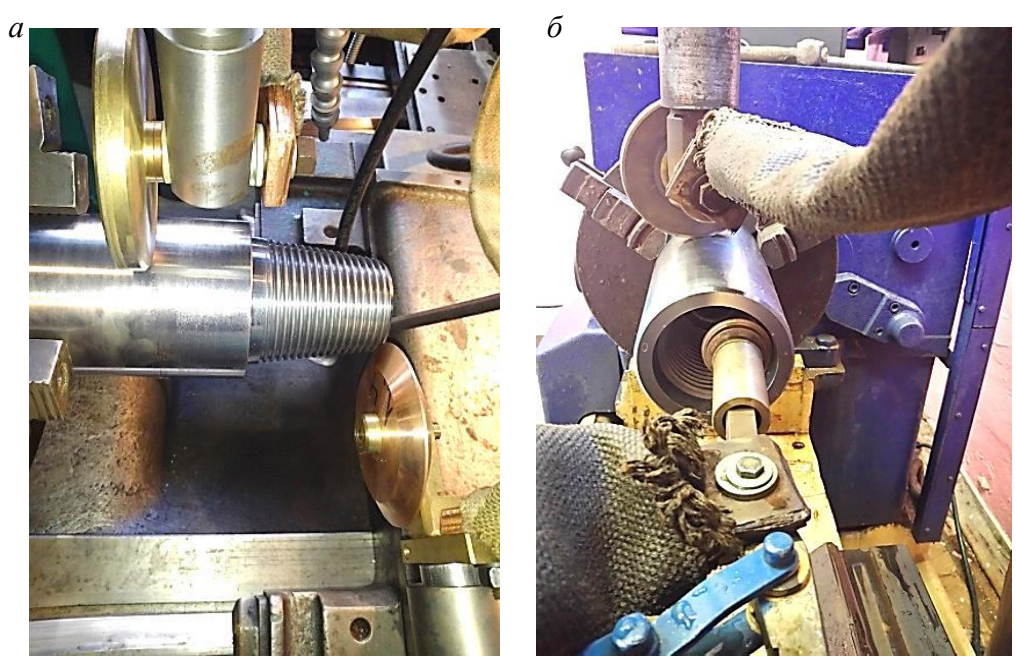

Рис.7. Фрагменты электромеханической обработки резьбы ниппеля (a) и муфты (б) переводника
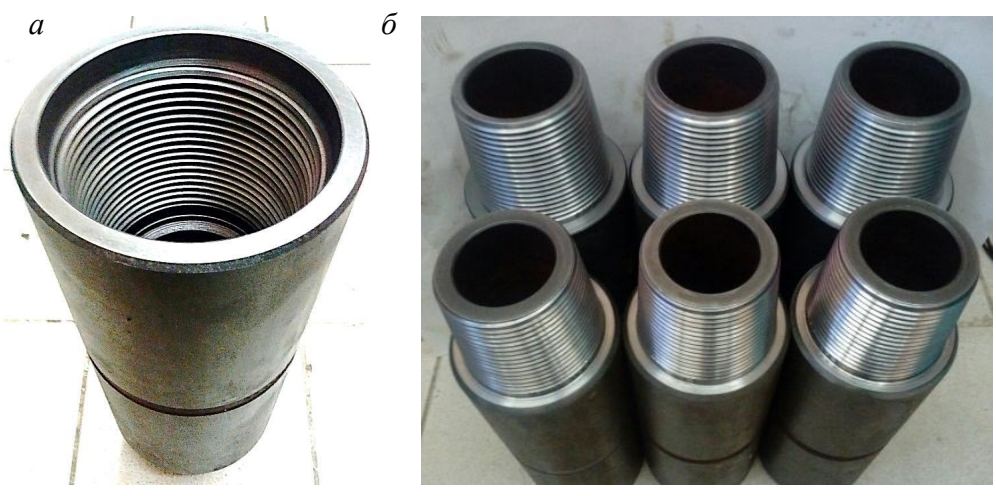

Рис.8. Фрагмент муфтовой $(a)$ и ниппельной (б) частей переводников производства ООО «ПТФ НИГМАШ» П-133/133 - 3 шт., П-147/147 - 3 шт. после электромеханической обработки резьбы замков бурильных труб, отрицательно влияет на износостойкость не только тела бурильного замка, но и на самое слабое место труб - резьбовые соединения. В сочетании с невысокой твердостью 210-260 HV и прочностью витков резьбы это приводит к низкой износостойкости резьбовых соединений и восстановлению их на трубных базах. Вопрос стойкости резьбовых соединений является «самым узким местом» жизненного цикла бурильной трубы с наплавленными по телу замками.

Металлографические и метрологические исследования переводников, изготовленных в условиях Александровского завода бурового оборудования (рис.7 и 8), стендовые испытания, проведенные на базе Ковровского завода бурового оборудования, подтвердили эффективность технологии ЭМО при навинчивании-свинчивании резьбовых соединений.

В условиях ООО «УК «Татбурнефть» проводятся эксплуатационные испытания переводников П-133/133, П-147/147 производства ООО «ПТФ НИГМАШ», изготовленных из стали 40ХН2МА с резьбой, подвергнутой ЭМО. Промежуточные результаты испытаний сви- 
Повышение долговечности переводников и бурильных труб...

детельствуют, что при бурении скважин после 978 циклов (норматив 500) навинчиваниясвинчивания переводников П-147/147, износа резьбы не зафиксировано.

\section{Выводы}

1. В работе были определены направления проведения исследований по повышению износостойкости замков бурильных труб, резьбовых соединений и обсадной бурильной колонны:

- нанесение на замок бурильных труб износостойких наплавок российскими и зарубежными материалами (хардбендинг);

- закалка поверхностного слоя замков бурильных труб электромеханической обработкой;

- закалка наружной и внутренней замковой резьбы бурильных труб электромеханической обработкой.

2. Производственный успех использования технологии нанесения износостойких наплавок на тело бурильного замка обусловлен:

- использованием простого и мобильного оборудования для сварки;

- проведением работ в местах использования бурильного инструмента или временных (постоянных) производственных базах с небольшим транспортным плечом от месторождения;

- повторным нанесением наплавочных материалов при восстановлении замков бурильных труб;

- широким и постоянно растущим списком компаний, которые получают аккредитацию на производство данных работ.

3. Химический состав наплавочных материалов указывает на наличие карбидообразующих элементов ( $\mathrm{Cr}, \mathrm{Ti}, \mathrm{Al}, \mathrm{V}, \mathrm{Nb}, \mathrm{Mn})$, неравномерно распределенных по наплавленному покрытию, увеличивающих твердость и образующих с углеродом простые или сложные карбиды, которые обладают высокой твердостью с сохранением достаточной вязкости.

4. Результаты износных испытаний наплавленных материалов в сравнении с материалами замков серийного производства (тест ASTM G65 на степень сопротивления абразивному износу) свидетельствуют об эффективности всех исследуемых образцов российского и зарубежного производства. В целом сохраняется прямая зависимость значений износостойкости от твердости материала наплавок.

5. Износостойкость наплавочных материалов НП 57, НП 58 (Интерпро, Россия) находится на уровне лучших исследованных мировых образцов Duraband NC, 13 CF (Castolin Eutectic). Однако для НП 57, НП 58 требуется доработка технологии нанесения наплавок и повышения качества выполненных покрытий.

6. Трибологические испытания (тест Casing Wear Test) также подтверждают эффективность российских и зарубежных наплавочных материалов. При этом материалы с относительно невысокой твердостью наплавок в меньшей степени изнашивают образец обсадной трубы, а износостойкость наплавленной поверхности замка более чем в 5 раз превышает износостойкость исходных образцов.

7. Испытания по двум видам тестов показали, что достичь универсальности наплавочных материалов сложно, но использование буровыми подрядчиками компоновок бурильной колонны с различными наплавками еще более сложнее, поэтому рекомендуется выбирать наплавочные материалы для нанесение на замки, которые дали бы лучшие средние результаты. По результатам показателей тестов к таким материалам мы могли бы отнести: Duraband NC, 13 CF (Castolin Eutectic) и при надлежащем качестве технологии нанесения российские материалы НП 57 и 58.

8. Химический состав материала замков российских и зарубежных производителей бурильных труб указывает на значительный разброс сталей по содержанию углерода $(0,22-0,37)$, что в сочетании с другими легирующими элементами соответствует маркам сталей 20ХГНМ-38ХГНМ.

9. Значительный разброс сталей, используемых для изготовления замков бурильных труб, отрицательно влияет на износостойкость не только тела бурильного замка, но и на самое слабое место труб - резьбовые соединения. В сочетании с невысокой твердостью 210-260 HV и прочностью витков резьбы это приводит к низкой износостойкости резьбовых соединений и необходимости их восстановления на трубных базах. Вопрос стойкости резьбовых соединений является «самым узким местом» жизненного цикла бурильной трубы с наплавленными по телу замками.

Записки Горного института. 2018. Т. 233. С. 539-546 • Электромеханика и машиностроение 
Повышение долговечности переводников и бурильных труб...

10. Технология ЭМО указывает на возможность повышения износостойкости замков и резьбы бурильных труб и переводников, обеспечивает сохранность обсадной колонны посредством закалки поверхностного слоя бурильных замков как альтернатива хардбендингу.

Коммерческий успех технологии ЭМО может быть продиктован следующим:

- стоимость оборудования для проведения технологии ЭМО незначительна и соизмерима со стоимостью мобильного комплекса по нанесению износостойких наплавок;

- расходные наплавочные материалы и защитные газы не требуются;

- ЭМО выполняется на металлорежущем станке токарем, нарезающим резьбу;

- производительность операции ЭМО равна времени нанесения износостойкой наплавки в тех же габаритах изделий;

- энергетическая составляющая затрат на порядок ниже, чем при наплавке;

- при ЭМО отсутствуют вредные и опасные факторы;

- повышение износостойкости наружной и внутренней замковой резьбы бурильных труб, переводников и переходников выполняется на трубонарезных станках.

\section{ЛИТЕРАТУРА}

1. Басарыгин Ю.М. Осложнения и аварии при бурении нефтяных и газовых скважин / Ю.М.Басарыгин, А.И.Булатов, Ю.М.Проселков. М.: Недра. 2000. 679 с.

2. Долгий И.Е. Сопротивление горных пород разрушению при бурении скважин / И.Е.Долгий, Н.И.Николаев // Записки Горного института. 2016. Т. 221. С. 655-660. DOI 10.18454/PMI.2016.5.655

3. Дафф K. Duraband NC уже более 7 лет успешно защищает используемые в России бурильные трубы // Бурение и нефть. 2016. № 9. С. 72-74.

4. Патент 2482942 РФ. Способ изготовления резьбы на детали / Л.В.Федорова, С.К.Федоров, В.С.Жаренников, М.В.Песин, Ю.П.Смольский. Заявл. 24.06.2011. Опубл. 27.05.2013. Бюл. № 15.

5. Патент 2486994 РФ. Способ изготовления резьбы на детали / Л.В.Федорова, С.К.Федоров, В.С.Жаренников, М.В.Песин, Ю.П.Смольский. Заявл. 24.06.2011. Опубл. 10.07.2013. Бюл. № 19.

6. ССК: Отчет по хардбендингу / А.В.Садовников, С.К.Федоров, Л.В.Федорова, А.М.Ломпас, О.И.Фомин // ROGTEC. Российские нефтегазовые технологии. 2017. № 49. С. 12-25.

7. Технологические основы повышения износостойкости деталей электромеханической поверхностной закалкой / С.К.Федоров, Л.В.Федорова, Ю.С.Иванова, А.М.Ломпас // Машиностроение. 2017. № 9 (690). С. 85-92. DOI: 10.18698/0536-1044-2017-9-85-92

8. Федорова Л.В. Повышение износостойкости резьбовых соединений бурильных труб электромеханической поверхностной закалкой / Л.В.Федорова, Ю.С.Иванова, М.В.Воронина // Записки Горного института. 2017. Т. 226. С. $456-461$. DOI: 10.25515/PMI.2017.4.456

9. Федорова Л.В. Электромеханическая обработка / Л.В.Федорова, С.К.Федоров // РИТМ. 2012. Т. 2. № 70. С. 14-16.

10. Хардбендинг как эффективный метод увеличения ресурса бурильных труб и защиты обсадной колонны. Результаты трибологических испытаний износостойких наплавок для бурильных замков / А.В.Садовников, С.К.Федоров, Л.В.Федорова, А.М.Ломпас, О.И.Фомин // Бурение и нефть. 2017. № 6. С. 30-35.

11. Шиловский А.В. Хардбендинг на защите бурильной трубы // Бурение и нефть. 2016. № 4. С. 58-59.

12. ЭМО для повышения надежности машин / С.К.Федоров, Л.В.Федорова, А.В.Садовников, Ю.С.Иванова, А.М.Ломпас, М.В.Власов // РИТМ. 2017. № 4. С. 96-98.

13. Electromechanical surface hardening of tubing steels / L.V.Fedorova, S.K.Fedorov, A.A.Serzhant, V.V.Golovin, S.V.Systero // Metal Science and Heat Treatment. 2017. Vol. 59. № 3. P. 173-175. DOI 10.1007/s11041-017-0123-Z

14. Increase of wear resistance of the drill pipe thread connection by electromechanical surface hardening / S.K.Fedorov, L.V.Fedorova, Yu.S.Ivanova, M.V.Voronina // International Journal of Applied Engineering Research. 2017. Vol. 12 . № 18. P. 7485-7489.

Aвторы: С.К.Федоров, д-р техн. наук, профессор, тотd@уапdех.rи (Московский государственныий технический университет им. Н.Э. Баумана, Москва, Россия), Л.В.Федорова, д-р техн. наук, профессор, Fedorova.lv@bmstu.ru (Московский государственный технический университет им. Н.Э.Баумана, Москва, Россия), Ю.С.Иванова, канд техн. наук, доцент, yyulianius@gmail.com (Московский государственный технический университет им. Н.Э.Баумана, Москва, Россия), М.В.Воронина, канд техн. наук, доиент, тагіа.vv@таil.ru (Санкт-Петербургский горный университет, Санкт-Петербург, Россия), А.В.Садовников, генеральный директор, m_tservis@mail.ru (ООО «Материальь Технологии Сервис», Москва, Россия), В.Н.Никитин, генеральный директор, пvп197б@таі.ги (ООО «Интехно», Ханты-Мансийский автономный округ Югра, г. Нижневартовск, Россия),

Статья поступила в редакциию 29.10.2017

Статья принята к публикации 02.04.2018. 